\title{
Accompaniment Support to the Patient with Cervical Cancer to the Psychology in Facing Chemotherapy in Edelweis Room at Ulin General Hospital Banjarmasin
}

\author{
Anggrita Sari ${ }^{1}$ \\ \{anggritasari@unism.ac.id | anggritasariangel@gmail.com ${ }^{1}$ \} \\ ${ }^{1}$ Sari Mulia University, Banjarmasin, South Kalimantan 70238, Indonesia
}

\begin{abstract}
Cervix Cancer prevalence in the world keeps increasing with a total of 529,409 cases. There are 17 per 100,000 women per year in Southeast Asia. There were 74,535 cases in Indonesia and 1,187 cases in South Kalimantan from 2007-2016. Data from the Edelweis room at Ulin General Hospital Banjarmasin, the cases of Cervix Cancer were 2015 (393), 2016 (419), and 2017 (462). This study aimed to analyze the effect of assistance support for Cervix Cancer patients on the psychology of patients facing chemotherapy in the Edelweis Room at Ulin General Hospital of Banjarmasin. The method in this study used Analytical Survey with a cross-sectional approach. The study sample was 60 people who suffered from Cervix Cancer who would face chemotherapy totaling 60 people taken by total sampling technique. The data analysis was used Kolmogorov-Smirnov. The study showed that respondents who were accompanied mainly by her husbands were $73.3 \%$ experiencing mild anxiety, and $26.7 \%$, experienced severe anxiety, showed $\rho$ value $=0.003<\alpha 0.05$. There was an effect of supporting the assistance of Cervix Cancer patients to their psychological in facing the chemotherapy in the Edelweis room at Ulin General Hospital Banjarmasin. The assistance support to Cervix Cancer patients is very important, especially in facing chemotherapy, so it is very necessary to assist family and health workers.
\end{abstract}

Keywords: Cervix Cancer, Chemotherapy, Assistance Support

\section{Introducation}

Cervical $\mathrm{Ca}$ is one of the serious health problems among women today and is the second leading cause of death after breast $\mathrm{Ca}$. The prevalence of Ca cervix in the world amounts to 529,409 cases, $89 \%$ of which occur in developing countries Thailand, Myanmar, Cambodia, and Indonesia [1]. Indonesia is ranked 4th in Southeast Asia with a cervical Ca incidence of 17 per 100,000 women per year [2].

Indonesia is one country that has many cases of cervical Ca. There are around 40,000 new cases of cervical Ca each year. In 2007-2016 in Indonesia, there were 74,535 cases of women diagnosed with cervical $\mathrm{Ca}$. For this, Indonesia ranks second of all types of $\mathrm{Ca}$ in women. Estimated rates of cervical Ca rate incidents in several cities, including Jakarta 100/100,000, Bali 152/100,000, Tasikmalaya 360/100,000, Sidoarjo 49/100,000 [3]. Data on the incidence of cervical Ca was also obtained in South Kalimantan with a total of 1,187 cases as of 2007-2016 [4]. 
Based on the data from cervical $\mathrm{Ca}$ patients in the Edelweis room at the Ulin General Hospital Banjarmasin, the number of visits of cervical $\mathrm{Ca}$ patients the last three years continued to increase, starting from 2015 (393 visits), 2016 (419 visits), and 2017 (462 visits). The average number of ca cervical patients in 1 month is 30 people. This situation illustrates that the incidence of cervical $\mathrm{Ca}$ in the South Kalimantan region is always increasing every year.

Chemotherapy is a therapy for malignancies that have spread or malignancies in which there are no other therapeutic options, before surgery, to reduce tumor size (neoadjuvant therapy) and after surgery, to reduce spread, recurrence (adjuvant therapy). Chemotherapy can cause several side effects such as nausea, vomiting, pain, diarrhea and hair loss. Chemotherapy can also cause a sore throat and dry mouth, causing pain and difficulty when eating and swallowing. These side effects can cause psychological effects of patients in the form of anxiety in patients undergoing chemotherapy.

Anxiety is a part of human life that is characterized by feelings of fear or anxiety that are deep and ongoing [5]. Excessive anxiety in chemotherapy patients can affect the motivation of patients in running chemotherapy, thus affecting the chemotherapy program [6]. Side effects caused when undergoing chemotherapy make the patient feel uncomfortable, fearful, anxious, lazy, and even biased to frustration or despair, with treatment so that Ca patients, in this case, need support from family [7].

Husband support or support in the process of chemotherapy is a source of strength for mothers that cannot be provided by health workers. The husband's support can be in the form of encouragement, motivation towards his wife both morally and materially as well as physical, psychological, emotional, information, judgment, and financial support. Minimum support in the form of touches and words of praise that make them comfortable and provide reinforcement during the chemotherapy process [8].

The research conducted by Amia (2017) shows that the majority of respondents did not get the support of 20 people $(58.8 \%)$ and the majority of respondents with a severe anxiety level of 20 people $(58.8 \%)$ so there is a relationship of family support with the level of anxiety Ca cervical patient [9]. This explanation is in line with research conducted by Enycosia (2017), which shows that mothers who are accompanied by their husbands have an average anxiety level of 15.46 while mothers who are not accompanied by their husbands have an average anxiety level of 26.40. So there is the influence of the husband's assistance to the level of patient anxiety in maternal cases, namely patients who have an abortion [10]. Based on the data and phenomena above, this research focused on Supporting Cervical Ca Patient's Support for the Psychology of Chemotherapy".

\section{Methods}

This research took place in the Edelweis room at Ulin General Hospital Banjarmasin for three months in 2018. This study used an analytical survey method with a cross-sectional approach to analyze the support of cervical Ca patients for psychological assistance in facing chemotherapy at Ulin General Hospital Banjarmasin.

The population in this study were all mothers suffering from cervical $\mathrm{Ca}$ who would face chemotherapy in the Edelweis room of Ulin General Hospital Banjarmasin, amounting to 113 people so that the average monthly amounted to 30 people. The sample in this study was 60 people with a total sampling technique. Data were analyzed using the Kolmogorov-Smirnov test. 


\section{Results}

\section{Respondents' Characteristics}

Table 1. Frequency distribution of cervical Ca respondents by age in the Edelweis Room of Ulin Hospital Banjarmasin.

\begin{tabular}{ccc}
\hline \multicolumn{1}{c}{ Ages } & Frequency & $(\%)$ \\
\hline$<20$ years & 0 & $0 \%$ \\
$21-60$ years & 58 & $93,3 \%$ \\
$>60$ years & 2 & $6,7 \%$ \\
Total & $\mathbf{6 0}$ & $\mathbf{1 0 0 \%}$ \\
\hline
\end{tabular}

Table 1 shows that the majority of respondents aged 21-60 years old are 58 people (93.3\%), while respondents $>60$ years are two people $(6.7 \%)$.

Table 2. Frequency distribution of cervical Ca respondents by occupation

\begin{tabular}{lcc}
\hline \multicolumn{1}{c}{ Occupation } & Frequency & $\mathbf{( \% )}$ \\
\hline Occupied & 4 & $13,3 \%$ \\
Unemployed & 56 & $86,7 \%$ \\
$\quad$ Total & $\mathbf{6 0}$ & $\mathbf{1 0 0 \%}$ \\
\hline
\end{tabular}

Table 2 shows that the majority of respondents work as unemployed, i.e., 56 people $(86.7 \%)$, while respondents who work as work are four people $(13.3 \%)$.

Table 3. Frequency distribution of cervical Ca respondents by the level of education

\begin{tabular}{|c|c|c|}
\hline Level of Education & Frequency & $(\%)$ \\
\hline Primary & 34 & $56,7 \%$ \\
\hline Secondary & 8 & $13,3 \%$ \\
\hline Secondary High & 10 & $16,7 \%$ \\
\hline College & 8 & $13,3 \%$ \\
\hline Total & 60 & $100 \%$ \\
\hline
\end{tabular}

Table 3 concludes that the majority of respondents with elementary education are $56.7 \%$ while respondents with secondary education are $13.3 \%$, respondents with high school education are $16.7 \%$, and respondents with a Bachelor's education are $13.3 \%$.

Table 4. Frequency distribution of cervical Ca respondents based on obstetric history

\begin{tabular}{|c|c|c|}
\hline Parity History & Frequency & $(\%)$ \\
\hline Primipara & 6 & $10,0 \%$ \\
\hline Multipara & 46 & $76,7 \%$ \\
\hline Grandmultipara & 8 & $13,3 \%$ \\
\hline Total & 60 & $100 \%$ \\
\hline
\end{tabular}


Table 4 concludes that the majority of respondents with primipara are $10 \%$, while respondents with multipara are $76.7 \%$, and respondents who are grand multipara are $13.3 \%$.

Table 5. Frequency distribution of cervical $\mathrm{Ca}$ respondents based on the history of contraception

\begin{tabular}{|c|c|c|}
\hline Contraception History & Frequency & $(\%)$ \\
\hline Hormonal & 52 & $86,7 \%$ \\
\hline Non-Hormonal & 8 & $13,3 \%$ \\
\hline Total & 60 & $100 \%$ \\
\hline
\end{tabular}

Table 5 shows that the majority of respondents who use hormonal contraception are $86.7 \%$, while respondents who use non-hormonal $13.3 \%$.

Table 6. Frequency distribution of cervical Ca respondents by stage $\mathrm{Ca}$

\begin{tabular}{|c|c|c|}
\hline Ca Stadium & Frequency & $(\%)$ \\
\hline $1 \mathrm{~B}$ & 6 & $10,0 \%$ \\
\hline $2 \mathrm{~B}$ & 8 & $13,3 \%$ \\
\hline $3 \mathrm{~A}$ & 12 & $20,0 \%$ \\
\hline $3 \mathrm{~B}$ & 34 & $56,7 \%$ \\
\hline Total & 60 & $100 \%$ \\
\hline
\end{tabular}

Based on table 6 it can be seen that the majority of respondents have entered stage $3 \mathrm{~B}$, namely 34 people $(56.7 \%)$, while other respondents entered stadium $1 \mathrm{~B}$, six people $(10 \%), 2 \mathrm{~B}$, eight people (13.3\%), 3A; 12 people $(20 \%)$.

Table 7. Frequency distribution of cervical $\mathrm{Ca}$ respondents based on the length of chemotherapy.

\begin{tabular}{lcc}
\hline Chemotherapy length & Frequency & $(\boldsymbol{\%})$ \\
\hline New (<1 years) & 56 & $93,3 \%$ \\
Longer (1-3 years) & 4 & $6,3 \%$ \\
Very long > 3 years & 0 & $0 \%$ \\
Total & $\mathbf{6 0}$ & $\mathbf{1 0 0 \%}$ \\
\hline
\end{tabular}

Table 7 shows that the majority of respondents had just undergone chemotherapy $(<1$ year) as many as 56 people $(93.3 \%)$, respondents who underwent chemotherapy for a long time (1-3 years) 4 people $(6.3 \%)$.

Univariate Analysis

Table 8. Frequency distribution of cervical Ca respondents based on accompaniment 


\begin{tabular}{lcc}
\hline \multicolumn{1}{c}{ Accompaniment } & Frequency & $(\boldsymbol{\%})$ \\
\hline Accompanied & 44 & $73,3 \%$ \\
Not accompanied & 16 & $26,7 \%$ \\
\multicolumn{1}{c}{ Total } & $\mathbf{6 0}$ & $\mathbf{1 0 0 \%}$ \\
\hline
\end{tabular}

Table 8 shows that the majority of respondents were accompanied by a husband of 44 people $(73.3 \%)$ respondents who were not accompanied by a husband of 16 people $(26.7 \%)$. Assistance is the act of accompanying, accompanying, and accompanying joy and sorrow. Assistance is the existence of someone who accompanies or is directly involved as a guide so that they can provide comfort to a particular process based on Sherly (2009).

This study is in line with research conducted by Prasetyani (2016) that their husbands accompanied most respondents as many as 48 people (68.6\%), assisting husbands had a good influence on psychological mothers, with the assistance of mother's husband tended only to experience moderate anxiety although the variables in the study differ from those studied by researchers, husband's support does greatly affect the psychological state of the mother.

Based on the results of the study above, family assistance is very necessary, especially done by the husband because the husband's mother who will undergo chemotherapy will feel calmer because the husband gives enthusiasm and support so that it slightly reduces the fear and anxiety that is being experienced by the woman.

Table 9. Frequency distribution of cervical Ca respondents based on anxiety level.

\begin{tabular}{|c|c|c|}
\hline Level of anxiety & Frequency & $(\%)$ \\
\hline Light & 40 & $66,7 \%$ \\
\hline Medium & 12 & $20,0 \%$ \\
\hline Extreme & 8 & $13,3 \%$ \\
\hline Total & 60 & $100 \%$ \\
\hline
\end{tabular}

Table 9 shows that the majority of respondents experienced mild anxiety by 40 people $(66.7 \%)$, respondents who experienced moderate anxiety 12 people $(20.0 \%)$, respondents who experienced severe anxiety eight people (13.3\%).

Patient's experience in undergoing treatment is very valuable experiences that occur in individuals, especially for the days to come. Early experience as an important part is even very decisive for an individual's mental state in the future. The individual experience about chemotherapy is less, and then it tends to affect the increase in anxiety when going to face chemotherapy [6].

The results of the respondents' anxiety levels were in the mild category, and this is because most respondents had more than $1 \mathrm{x}$ underwent chemotherapy, so the level of anxiety when facing chemotherapy was lower.

This study is in line with Utami's (2013) research on the relationship of family support to the level of chemotherapy anxiety in cervical Ca patients, mentioning that of 95 cervical $\mathrm{Ca}$ patients, $58(61.1 \%)$ patients experienced mild anxiety [11].

Based on research results above cervical Ca patients who face chemotherapy more than 1 times tend to have lower anxiety because they already have prior chemotherapy experience, apart from the chemotherapy experience that has been undertaken by $\mathrm{Ca}$ cervical patients, 
support from family, especially from the husband can affect the anxiety level of cervical Ca patients that will face chemotherapy.

\section{Bivariate Analysis}

Table 10. Effects of Husband's Mentoring on Anxiety Levels by the Kolmogorov-Smirnov Test

\begin{tabular}{|c|c|c|c|c|c|c|c|c|c|}
\hline \multirow{2}{*}{ Husband's Support } & \multicolumn{6}{|c|}{ Anxiety Level } & \multicolumn{2}{|c|}{ Total } & \multirow{2}{*}{$\begin{array}{c}\mathbf{P} \\
\text { value }\end{array}$} \\
\hline & $\mathbf{n}$ & $\%$ & $\mathbf{n}$ & $\%$ & n & $\%$ & $\mathbf{N}$ & $\%$ & \\
\hline Accompanied & 38 & 63.3 & 6 & 10.0 & $\overline{0}$ & 0 & 44 & 73.3 & \\
\hline Not accompanied & 2 & 3.3 & 6 & 10.0 & 8 & 13.3 & 16 & 26.7 & 0.003 \\
\hline Total & 40 & 66.7 & 12 & 20 & 8 & 13.3 & 60 & 100 & \\
\hline
\end{tabular}

Table 10 shows that the Kolmogorov-Smirnov test results obtained values $(\rho=0.003<\alpha$ $=0.05)$. With the results, $\rho=0.003$ shows that there is a significant effect between the assistance of the husband of the cervical $\mathrm{Ca}$ patients to the level of anxiety facing chemotherapy. Appropriate husband assistance and following what is needed by the patient can improve life and provide new energy to live a better life and focus on improving the meaning of life. Conversely, improper husband assistance can increase the burden on the mind and will greatly affect the level of patient anxiety, for that husband and health workers are expected to be able to provide good motivation and support so that patients undergoing chronic dialysis are able to control the stressors experienced which can improve the quality of life of patients with chronic health problems.

This study is in line with the study of Khusniyah \& Mukhoirotin (2010), which states that there is an influence of husband's assistance on the decrease in anxiety level with a value ( $\rho=0.045<\alpha=0.05$ ) [12]. One of the factors that influence the anxiety level of patients undergoing chemotherapy is the age of the respondent, the results of most research conducted by respondents from the age of $>35$ years. Age is a period of adjustment to new life patterns and new hopes. Age can affect knowledge that is caused by increasing a person's age and will experience physical and mental changes and patterns of thought so that a woman is vulnerable to the risk of various diseases, one of which is cervical Ca [13]. Research, according to Setyarini (2009), found that respondents aged $>35$ years were at risk of developing Ca uterus 4.23 times greater than respondents aged $<35$ years [14].

Apart from the responsive age, the mother's education level also affects the level of anxiety in which from this study, the highest level of education is 34 students $(56.7 \%)$. The level of education with the incidence of cervical $\mathrm{Ca}$ there is a strong relationship, where cervical $\mathrm{Ca}$ tends to be more common in women with low education compared to women with high education $(88.9 \%)$. High and low education is related to socioeconomic level, sex life, and cleanliness, according to Surbakti (2008) in Damayanti (2013) [15].

From the data of respondents, most of the mothers did not work, namely 26 people $(86.7 \%)$. This study is in line with Sari's research (2018), said that of the 66 respondents, 44 people $(66.67 \%)$ were unemployed or unemployed. Work is at risk for cervical Ca. Work is also related to individual social activities, so by working, individuals can easily find information from outside, both information related to daily needs and health information. Allegedly socioeconomic conditions or low-income levels are associated with the utilization of health services at a low level of prevention [16]. 
From the data of respondents, most of the respondents who used hormonal contraception were 26 people $(86.7 \%)$. The use of hormonal contraception for more than 4 or 5 years can increase the risk of cervical Ca 1.5 - 2.5 times. Several studies have shown that oral contraceptives cause women to be sensitive to HPV, which can cause inflammation in genitalia so that there is a risk of cervical Ca (Hartmann, 2002) in Damayanti (2013) [17].

Data from respondents, most of the mothers underwent chemotherapy ( $<1$ year) as many as 28 people $(93.3 \%)$. Hence respondents who have had treatment for less than one year have high self-confidence to recover while respondents who have been undergoing treatment for $>$ 3 years but have severe anxiety. This is due to respondents feeling hopeless and lacking support from their families.

Excessive anxiety in cervical Ca patients can result in decreased endurance or immunity, increasing the risk of heart problems, a decrease in chemotherapy conditions can cause some side effects such as nausea, vomiting, pain, diarrhea, and hair loss. Chemotherapy can also cause a sore throat and dry mouth, causing pain and difficulty when eating and swallowing. This can cause loss of appetite, medically, the effects of chemotherapy on appetite due to the release of cytokines such as TNF and interleukin which cause the hypothalamus to react by reducing hunger and causing nausea, besides other chemotherapy effects that can be felt by $\mathrm{Ca}$ sufferers are diarrhea, taste like there is metal in the mouth and decreased appetite like anorexia [18].

\section{Conclusion}

Patients suffering from cervical $\mathrm{Ca}$ who face chemotherapy had different levels of anxiety - apart from the factors that can affect the occurrence of cervical $\mathrm{Ca}$, previous chemotherapy experience can also be a trigger for the decline in anxiety levels experienced by the women because they had never had any treatment with chemotherapy must-have can adapt to the side effects that will be caused by the chemotherapy it does. Mothers who undergo chemotherapy also need support from other people, both from partners, family, friends and even from the social environment.

Health workers and husbands are also encouraged to provide support and enthusiasm for patients to recover by providing the latest information about treatment or how to reduce the risk of cervical $\mathrm{Ca}$, provide patient support for routine chemotherapy, not isolate the patient and pay attention to the patient's nutritional intake.

\section{Acknowledgement}

I would like to thank to all of women who generously participate in this study as well as the nurses and midwives in the Ulin General Hospital of Banjarmasin. This study was supported by Sari Mulia University, Banjarmasin, South Kalimantan, Indonesia.

\section{References}

[1] American Cancer Society (ACS). Cancer Fact and figures. INC. [Internet]. Available at: dari http://www.cancer.org/. [Diakses 2 Februari 2018]. (2016)

[2] Human Papilloma Virus Information Center

[3] Kementrian Kesehatan Republik Indonesia. Laporan Hasil Riset Kesehatan Dasar (Riskesdas) Indonesia Tahun 2013. [Internet]. Tersedia dalam: http://www.depkes.go.id. [Diakses 2 februari 2018].

[4] Data and Information on Indonesian Health Profile. (2013) 
[5] Nadeak. Hubungan Dukungan Keluarga dengan Tingkat Kecemasan Pasien Pre Operasi di Ruangan RB2 RSUP HAM. Skripsi. [internet]. Tersedia dalam: http://repository.usu.ac.id. [Diakses 10 Juli 2018]. (2010)

[6] Lutfa U, Maliya A. Faktor-Faktor Yang Mempengaruhi Kecemasan Pasien Dalam Tindakan Kemoterapi di Rumah Sakit Dr. Moewardi Surakarta. Skripsi. [internet]. Tersedia dalam: www.eprints.ums.ac.id. [Diakses 25 Juli 2018]. (2008).

[7] Ratna W, 2010. Hubungan Dukungan Keluarga Dengan Kecemasan Pasien Ca Serviks Dalam Menjalani Proses Kemoterapi Di Balai Pengobatan Ukhuwah Malang. Jurnal Kesehatan. Edisi 6 hal 11 - 14. Universitas Airlangga [Internet] tersedia di. http//:www.healthy.co.id. [diakses 2 Februari 2018].

[8] Pfaedler, K.S., Wenzel, L., Mechanic, M.B., \& Penner, K.R. Cervical cancer survivorship: Long-term quality of life and social support. Clin Ther. Jan 1; 37(1): 39-48. (2015)

[9] Nyambe, A., Kampen, J.A., Baboo, S.K., \& Gan, G.V. Knowledge, attitudes and practices of cervical cancer prevention among Zambian women and men. BMC Public Health volume 19, 508. (2019).

[10] Vermeer, W.M., Bakker, R.M., Kenter, G.G., Stiggelbout, A.M., \& ter Kuile, M.M. Cervical cancer survivors' and partners' experiences with sexual dysfunction and psychosexual support. Support Care Cancer. 2016; 24: 1679-1687. (2016)

[11] Utami, Dewi. Hubungan Dukungan Keluarga Terhadap Tingkat Kecemasan Kemoterapi Pada Pasien Ca serviks di RSUD. Dr. Moewardi. KTI. [internet]. Tersedia dalam: http://jurnal.stikes-aisyiyah.ac.id. [Diakses 26 Juli 2018]. (2013)

[12] Mukhrotin, Khusniyah. Pengaruh pendampingan suami terhadap tingkat kecemasan pada proses persalinan kala I (fase laten - fase aktif). Skripsi. [internet]. Tersedia dalam: http://media.neliti.com. [Diakses 10 Juli 2018]. (2010)

[13] Notoatmodjo. Metodelogi Penelitian Kesehatan. Jakarta: Rineka Cipta. (2010)

[14] Setyarini E. 2009. Faktor faktor yang berhubungan dengan kejadian kanker leher Rahim di RSUD dr. Moewardi Surakarta. Surakarta: Fakultas Ilmu Kesehatan Masyarakat Universitas Muhammadiyah Surakarta. Skripsi. [Internet]. Tersedia dalam: http://eprints.ums.ac.id. [Diakses 26 Juli 2018].

[15] Subakti E. Pendekatan Faktor Resiko Sebagai Rencana Alternatif Dalam Penanggulangan Kanker Serviks Uteri di RS Pirngadi Medan.Tesis. [Internet]. Tersedia dalam: http://repository.usu.ac.id. [Diakses 26 Juli 2018]. (2004).

[16] Sari, Anggrita: Mahdiyah, Dede: Rahayu, Puji, Yayuk: Palimbo, Adriana. The Correlation between Characteristics, Knowledge, and Motivation of Couple in Childbearing Age with the Early Detection of Cervical Cancer in Ulin General Hospital Banjarmasin. Journal Research And Analysis. (2018)

[17] Damayanti. Faktor - faktor Yang Berhubungan Dengan Kejadian Kanker Serviks di RSUD Arifin Achmad Pekanbaru Tahun 2008-2010. Jurnal Kesehatan Komunitas.(2):8893. (2013).

[18] Prodjosudjadi, W. Glomerulonephritis. Buku Ajar Ilmu Penyakit Dalam Jilid I. Edisi Keempat. Jakarta: Pusat Penerbitan Departemen Ilmu Penyakit Dalam FKUI. (2014). 